\title{
University OF Wyoming-National PARK SERVICE RESEARCH CENTER AND JACKSON HOLE BIOLOGICAL RESEARCH STATION RESEARCH BIBLIOGRAPHY (1951-1991)
}

Alleman, D.D. 1975. Pilot plant study of a treatment system for recreational area vault toilet waste. J. Water Pollution Control 42:377-385.

Altmann, M. 1951. Patterns of herd structure in free-ranging elk. Anatomy Rec. 3:74.

Altmann, M. 1952. Social behavior of elk, Cervus canadensis nelsoni, in the Jackson Hole area of Wyoming. Behavior 4:116-143.

Altmann, M. 1953. Social graces in elk society. Ani. Kingdom $56: 66-72$.

Altmann, M. 1956. Patterns of herd behavior in free-ranging elk of Wyoming, Cervus canadensis nelsoni. Zoologica 41:6571.

Altmann, M. 1958. The flight distance in free-ranging big game. J. Wildl. Manage. 22:207-209.

Altmann, M. 1958. Social integration of the moose calf. Ani. Behav. 6:155-159.

Altmann, M. 1959. Group dynamics in Wyoming moose during the rutting season. J. Mammal. 40:420-424.

Altmann, M. 1960. Moose runs from Sandhill Crane. J. Mammal. 41:525.

Altmann, M. 1960. The role of juvenile elk and moose in the social dynamics of their species. Zoologica 45:35-39.

Altmann, M. 1961."Teen-age" problems in the wilderness. Ani. Kingdom 64:41-44.

Altmann, M. 1963. Naturalistic studies of maternal care in moose and elk. pp. 233-253. In: Maternal Behavior in Mammals. (H. L. Rheingold, ed.). John Wiley \& Sons.

Altmann, M. 1963. Seniors of the wilderness. Ani. Kingdom 66:181-183

Altmann, M. 1965. Messages in the wild. Ani. Kingdom 68:179182.
Altmann, M., R.D. Taber and A. de Vos. 1956. Two marking devices for large land mammals. J. Wildl. Manage. 20:464.

Anderson, S.H., W.A. Hubert, A.J. Redder and D.Duvall. 1987. Distribution of vertebrates of the Bighorn Canyon NRA. Great Basin Nat. 47:512-521.

Armitage, K.B. 1959. Behavior patterns of juvenile yellow-bellied marmots (Marmota flaviventris nosophora Howell). Anat. Rec. 134:525.

Armitage, K.B. 1961. Frequency of melanism in the goldenmantled marmot. J. Mammal. 42:100-101.

Armitage, K.B. 1962. Social behavior of a colony of the yellowbellied marmot (Marmota flaviventris). Ani. Behav. 10:319331.

Armitage, K.B. 1965. Vernal behavior of the yellow-bellied marmot (Marmota flaviventris). Ani. Behav. 13:59-68.

Ault, K.L. 1980. Ecology of the breeding bald eagle and osprey in the Grand Teton-Yellowstone National parks complex. M.S. Thesis. Montana State Univ., Bozeman. 95 pp.

Bailey, J.P. 1976. Seismicity and contemporary tectonics of the Hegben Lake-Centennial Valley, Montana area. M.S. Thesis. Univ. of Utah, Salt Lake City.

Bangham, R. 1951. Parasites of fish in the Upper Snake River drainage and in Yellowstone Lake, Wyoming. Zoologica $36: 213-217$.

Barnosky, A.D. 1984. The Colter Formation: evidence for miocene volcanism in Jackson Hole, Teton County, WY. Earth Sci. Bull. 17:49-97.

Barnosky, A.D. 1985. Late blancan (pliocene) microtine rodents from Jackson Hole, Wyoming: biostratigraphy and biogeography. J. Vert. Paleon. 5:255-271.

Barnosky, A.D. 1986. Arikareean, hemingfordian, and barstovian mammals from the Miocene Colter Formation, Jackson Hole, Teton County, WY. Bull. of Carnegie Mus. of Nat. Hist. No. 26.69 pp. 
Barnosky, A.D. 1986. New species of the miocene rodent Cupidinimus (Heteromyidae) and some evolutionary relationships within the genus. J. Vert. Paleon. 6:46-64.

Barnosky, A.D., W.J. Labar, and C.W. Barnosky. 1988. Paleoenvironmental implications of Barstovian lake deposits, mammals, and pollen from Hepburn's Mesa in the Yellowstone Valley, Park County, southwest Montana [Abstract]. Geol. Soc. of Am., Rocky Mountain Section meetings, Sun Valley, Idaho.

Barnosky, C.W. 1984. Late miocene vegetational and climatic variations inferred from a pollen record in Northwest Wyoming. Science 223:49-51.

Barnosky, C.W. 1987. Response of vegetation to climatic changes of different duration in the late Neogene. Trends In Ecology and Evolution 2:247-250.

Barnosky, C.W., P.M. Anderson, and P.J. Bartelein. 1987. The northwestern U.S. During deglaciation:vegetational history and paleoclimatic implications. pp. 289-321. In: North America and adjacent oceans during the last deglaciation (W.F. Ruddiman and H.E. Wright, Jr., eds.). The Geology of North America, vol. K-3. Geological Society of America, Boulder.

Barnosky, C.W. and S.G. Crumley. 1989. Establishing a postglacial fire history for Yellowstone National Park [abstract]. Second annual meeting of research and monitoring on Yellowstone's northern range. Yellowstone National Park. Mammoth, Wyo.

Barnosky, C.W., and H.E. Wright, Jr. 1989. Limnological and environmental changes inferred from the sediment of small lakes in the northern range of Yellowstone National Park [abstract]. Examining the Greater Yellowstone Ecosystem: a symposium on land and resource management. University of Wyoming, Laramie.

Baxter, J.W. 1960. Aquatic hyphomycetes from Wyoming. Mycologia 52:654-655.

Beetle, A.A. 1952. A 1951 survey of summer elk range in the Teton wilderness area. Wyoming Range Manage. 51:1-5.

Beetle, A.A. 1959. New names within the section Tridentatae of Artemisia. Rhodora 61:82-85.

Beetle, A.A. 1960. A study of sagebrush. Bull. 368, Univ. of Wyo. Agri. Exper. Sta., Laramie.

Beetle, A.A. 1961. Range survey in Teton County, Wyoming. Part I. Ecology of range resources. Bull. 376, Univ. of Wyo. Agri. Exper. Sta., Laramie.

Beetle, A.A. 1962. Range survey in Teton County, Wyoming. Part II. Utilization and condition classes. Bull. 400, Univ. of Wyo. Agri. Exper. Sta., Laramie.

Beetle, A.A. 1966. A 1966 survey of summer elk range in southern Yellowstone. Wyoming Range Manage. 223:196198.

Beetle, A.A. 1968. Range survey in Teton County, Wyoming. Part III. Trends in vegetation. Res. J. 26. Univ. of Wyo. Agri. Exper. Sta., Laramie.
Beetle, A.A. 1968. Another note on sagebrush taxonomy. Rhodora 70:782.

Beetle, A.A. 1970. Recommended plant names. Univ. Wyo. Agri. Exper. Sta. Res. J. 31:1-124.

Beetle, A.A., W.D. Fronk and D.G. Fullerton. 1964. Dipterous gall on the Artemisia tridentata complex and insects associated with them. Ann. Entomol. Soc. of Am. 57:575577.

Beetle, A.A., and A. Young. 1966. A third subspecies in the Artemisia tridentata complex. Rhodora 67:405-406.

Beetle, A.A., and M. May. 1970. Grasses of Wyoming. Univ. Wyo. Agri. Exper. Sta. Res. J. 39:1-151.

Beetle, D. 1956. Habitats of terrestrial mollusca in Jackson Hole, Wyoming. J. Colo.-Wyo. Acad. Sci. 55:43.

Beetle, D. 1957. The mollusca of Teton County, Wyoming. The Nautilus 71:12-22.

Beetle, C. 1960. Noteworthy records of Wyoming Mollusca. The Nautilus 73:155-157.

Benz, H.M. and R.B. Smith. 1984. Simultaneous inversion for lateral velocity variations and hypocenters in the Yellowstone region using earthquake and refraction data. J. Geophys. Res. 89:1208-1220.

Bergstrom, R.C. 1975. The prevalence of Dictyocaulus viviparus infection in Rocky Mountain elk in Teton County, Wyoming. J. Wildl. Dis. 11:40-44.

Bergstrom, R.C., and R. Robbins. 1979. Lungworms, Dictyocaulus viviparus, in various age classes of elk (Cervus canadensis) in the Tetons. pp. 221-223. In: North American Elk Ecology, Ecol. Behav. and Manage. Symp. Univ. of Wyo. April 3-5, 1978.

Bergstrom, R.C., S.L. Etherton and M.A. MacDonald. 1984. Controlling concurrent infections of Trichostrongylids and Coccidia in weaner calves. Vet. Med. 1210-1211.

Bick, G.H. and L.E. Hornuff. 1972. Odonata collected in Wyoming, South Dakota, and Nebraska. Proc. Entomol. Soc. Wash. 74:1-8.

Bliss, L.C. 1956. A comparison of plant development in microenvironments of arctic and alpine tundras. Ecol. Monogr. 26:303-337.

Bock, C.E. 1987. Avian habitat occupancy following fire in a Montana shrubsteppe. Prairie Nat. 19:153-158.

Bock, C.E. and J.H. Bock. 1983. Responses of birds and deer mice to prescribed burning in ponderosa pine. J. Wildl. Manage. 47:836-840.

Bock, J.H. and C.E. Bock. 1984. Effect of fires on woody vegetation in the Pine-grassland ecotone of the Southern Black Hills. Am. Midland Nat. 112:35-42.

Bock, J.H. and C.E. Bock. 1989. Ecology and evolution in the Great Plains. pp. 551-577. In: The Evolutionary Ecology of Plants. (J. Bock and Y. Linhart, eds.). Westview Press. Boulder, CO. 
Bock, J.H., W.D. Bowman, and C.E. Bock. 1991. Fire and global change in the High Plains of North america. Great Plains Res. 1:2.

Braile, L.W., R.B. Smith, J. Ansorge, M.R. Baker, M.A. Sparlin, C. Prodehl, N.M. Schilly, J.H. Healy, S. Mueller and K.H. Olsen. 1982. The Yellowstone Snake River Plain seismic profiling experiment: Crustal structure of the eastern Snake River Plain. J. Geophys. Res. 84:2597-2610.

Brewer, C.A. 1986. An investigation of the aquatic macrophyte community in Jackson Lake, Wyoming: Distribution, effect of moving water, and species-specific tensile properties. M.S. Thesis. Dept. Zoology and Physiology. Univ. Wyoming, Laramie. 156 pp.

Brewer, C.A. and M. Parker. 1990. Adaptations of macrophytes to life in moving water: upslope limits and mechanical properties of stems. Hydrobiologia 194:133-142.

Brokaw, M. 1985. Two-dimensional seismic models of the Yellowstone caldera. M.S. Thesis. Univ. of Utah, Salt Lake City.

Buchheim, H.P. 1990. Paleoenvironments and deposition of the Fossil Butte member of the Eocene Green River Formation, Wyoming. Geol. Soc. Am., Abstracts. 22:6.

Buchheim, H.P., and R.E. Biaggi. 1988. Laminae counts within a synchronous oil shale unit: a challenge to the "varve" concept. Geol. Soc. Am., Abstracts. 22:7.

Buchheim, H.P., and H.P. Eugster. 1986. Paleoenvironmental constraints controlling deposition of oil shale in Eocene Fossil Lake, Wyoming. AAPG Annual Meeting, Atlanta Georgia; Abstract in American Association of Petroleum Geologists Bull. 70:5.

Calder, W.A. 1968. Temperature relations and underwater endurance of the smallest homeothermic diver. Am. Zool. 8:145.

Calder, W.A. 1969. Temperature relations and underwater endurance of the smallest homeothermic diver, the water shrew. Comp. Biochem. Physiol. 30:1075-1082.

Calder, W.A. 1970. Use of a dipper nest by mountain bluebird. Condor 72:498.

Calder, W.A. 1971. Temperature relationships and nesting of the calliope hummingbird. Condor 73:314-321.

Calder, W.A. 1976. Energy crisis of the hummingbird. Nat. Hist. 85:24-29.

Carpenter, C. 1953. Aggregation behavior of tadpoles of Rana p. pretiosa. Herpetologica 9:77-78.

Carpenter, C. 1953. An ecological survey of the herpetofauna of the Grand Teton-Jackson Hole area of Wyoming. Copeia 3:170-174.

Carpenter, C. 1954. A study of amphibian movement in the Jackson Hole Wildlife Park. Copeia 3:197-200.

Clark, T.W. 1971. Aberrant coloration in Microtus pennsylvanicus from Grand Teton National Park, Wyoming. Northwest. Sci. 45:226-228.
Clark, M.L. and T.W. Clark. 1971. Key to 22 selected flowering plants based on leaf epidermal morphology from Jackson Hole, Wyoming. Wyoming Range Manage. 288:52-60.

Clark, T.W. 1971. Seasonal activity, habitat, reproduction and food uses of the western jumping mouse in Grand Teton National Park, Wyoming. Northwest Sci. 45:229-238.

Clark, T.W. 1971. Ecology of the western jumping mouse in Grand Teton National Park, Wyoming. Northwest Sci. 45:229-238.

Clark, T.W. 1973. Distribution and reproduction of shrews in Grand Teton National Park, Wyoming. Northwest Sci. 47:128-131.

Clark, T.W. 1974. Local distribution and interspecies interactions in microtines, Grand Teton National Park, Wyoming. Great Basin Nat. 33:205-217.

Clark, T.W. 1975. Ecological note on deer mice in Grand Teton National Park, Wyoming. Northwest Sci. 49:14-16.

Clark, T.W. 1975. Body measurements of western jumping mice from Northwestern Wyoming. Northwest Sci. 49:12-13.

Clark, T.W. 1979. Population organization and regulating mechanisms of pine martens in Grand Teton National Park, Wyoming. Proc. First Conf. Sci. Res. National Parks. 1:293-295.

Clark, T.W. and C. Russel. 1977. Agonistic behavior patterns in the Uinta ground squirrel. Northwest Sci. 51:36-42.

Clark, T.W., I. Belan and P. Lehner. 1978. Vocalizations of the American pine marten (Martes americana). J. Mammal. 59:871-874.

Clark, T.W. and T.M. Campbell. 1980. Short-term logging affects on rodents. Great Basin Nat. 40:133-189.

Clawson, S. 1981. The lateral inverse Q-structure of the upper crust in Yellowstone National Park from seismic refraction data. M.S. Thesis, Univ. of Utah, Salt Lake City.

Cody, M.L. 1974. Competition and the structure of bird communities. Monogr. Pop. Biol. \#7, Princeton Univ. Press, Princeton, NJ. 318 pp.

Cody, M.L. and R.I. Yeaton. 1974. Competitive release in island song sparrow populations. Theor. Pop. Biol. 5:42-58.

Collins, T.C. 1976. Population characteristics and habitat relationships of beavers (Castor canadensis) in northwest Wyoming. Ph.D. Thesis. Univ. of Wyo., Laramie. 177 pp.

Collins, T.C. 1979. Stream flow effects on beaver populations in Grand Teton National Park. Proc. First Conf. Sci. Res. National Parks. 1:349-3553.

Craighead, F.C. and J. J. Craighead. 1949. Nesting Canada geese on the Upper Snake River. J. Wildl. Manage. 13:51-64.

Cummins, G.B. and J.W. Baxter. 1962. Nomenclature, life histories, and records of North American Uredinales. Madrono 16:201-203. 
Czaplewski, R.L. 1972. Evolution of terminal consumers in a steady state regime. M.S. Thesis, Univ. Wyo., Laramie, 54 pp.

Czaplewski, R.L. and M. Parker. 1973. Use of a BOD oxygen probe for estimating primary productivity. Limnology and Oceanography 18:152-154.

Davis, P.R. 1977. Cervid response to forest fire and clear cutting in southeastern Wyoming. J. Wildl. Manage. 41:785-788.

Denniston, R.H. 1948. Certain aspects of the behavior of the Wyoming moose. J. Colo.-Wyo. Acad. of Sci. 3:55.

Denniston, R.H. 1949. The development of a calf moose. J. Colo.-Wyo. Acad. of Sci.. 4:58.

Denniston, R.H. 1956. Ecology, behavior and population dynamics of the Wyoming or Rocky Mountain moose, Alces alces shiras. Zoologica 41:105-118.

Diem, K.L. 1979. White pelican reproductive failures in the Molly Islands breeding colony in Yellowstone National park. Proc. First Conf. Sci. Res. National Parks. 1:489-496.

Diem, K.L. and G.S. Kennington. 1979. Rhyolite radionuclide uptake by selected plant species and pocket gophers in Yellowstone National Park. Proc. First Conf. Sci. Res. National Parks. 1:301-305.

Dimmick, R.W. 1968. Canada geese of Jackson Hole. Bull. No. 11, Wyo. Game and Fish Comm. Cheyenne. 86 pp.

Dodson, G.N., G.K. Morris, and D.T. Gwynne. 1983. Mating behavior of the primitive orthopteran genus Cyphoderris (Haglidae). pp. 305-318. In: Orthopteran Mating Systems: Sexual Competition in a Diverse Group of Insects, (D.T. Gwynne and G.K. Morris, eds.). Westview Press, Boulder, CO.

Doser, D.I. 1985. Source parameters and faulting processes of the 1959 Hebgen Lake, Montana, earthquake sequence. J. Geophys. Res. 90:4537-4556.

Doser, D.I. and R.B. Smith. 1983. Seismicity of the Tetonsouthern Yellowstone region, Wyoming. Bull. Seismol. Soc. Am. 73:1369-1394.

Edwards, W.C. 1964. A preliminary investigation concerning the plant ecology for the willow flats on Jackson Lake, Jackson Hole, Wyoming. Nebraska Acad. Sci. 74:6-7.

Emlen, J.T. 1952. Social behavior in nesting cliff swallows. Condor 54:177-199.

Emlen, J.T. 1954. Territory, nest building, and pair formation in the cliff swallow. Auk 71:16-35.

Engstrom, D.R., C. Whitlock, S.C. Fritz, and H.W. Wright, Jr. 1991. Recent environmental changes inferred from the sediments of small lakes in Yellowstone's Northern Range. J. Paleolimnology 5:139-174.

Evans, H.E. 1963. Predatory wasps. Sci. Am. 208:145-154.

Evans, H.E. 1963. Notes on the prey and nesting behavior of some solitary wasps of Jackson Hole, Wyoming. Entomol. News 74:233-239.
Evans, H.E. 1965. Simultaneous care of more than one nest by Ammophila azteca Cameron (Hymenoptera, Sphecidae). Psyche 72:18-23.

Evans, H.E. 1966. The comparative ethology and evolution of the sand wasps. Harvard Univ. Press. 526 pp.

Evans, H.E. 1966. The accessory burrows of digger wasps. Science 152:465-471.

Evans, H.E. 1966. Nests and prey of two species of Philanthus in Jackson Hole, Wyoming (Hymenoptera, Sphecidae). Great Basin Nat. 26:35-40.

Evans, H.E. 1968. The hunt of the wasps at Jackson Hole. Nat. Hist. 77:38-39.

Evans, H.E. 1970. Ecological-behavioral studies of the wasps of Jackson Hole, Wyoming. Bull. Mus. Comp. Zool. 140:451511.

Evans, H.E. 1973. Further studies on the wasps of Jackson Hole, Wyoming (Hymenoptera, Aculeata). Great Basin Nat. 33:147-155.

Evans, H.E. and J.E. Gillaspy. 1964. Observations on the ethology of digger wasps of the genus Steniolia (Hymenoptera: Bembicini). Am. Midl. Nat. 72:257-280.

Evans, H.E.and K.M. O'Neill. 1978. Alternative mating strategies in the digger wasp Philanthus zebratus Cresson. Proc. of the Natl. Acad. of Sci. 75:1901-1903.

Evans, H.E. and K.M. O'Neill. 1983. Patterns of prey use in four sympatric species of Philanthus (Hymenoptera:Sphecidae) with a review of prey selection in the genus. J. Nat. Hist. 16:791-801.

Evans, H.E. and K.M. O'Neill. 1983. Body size and alternative mating tactics in the beewolf Philanthus zebratus (Hymenoptera:Sphecidae). Biol. J. Linnaean Soc. 20:175 184.

Evans, H.E. and K.M. O'Neill. 1988. The natural history and behavior of North American Beewolves. Comstock Publishing Associates. $278 \mathrm{pp}$.

Evans, H.E. and K.M. O'Neill. 1991. Beewolves. Sci. Am. 265:70-76

Evoy, J. 1978. Precision gravity reobservations and simultaneous inversion of gravity and seismic data for subsurface structure of Yellowstone. M.S. Thesis, Univ. of Utah. Salt Lake City.

Findley, J.S. 1951. Habitat preferences of four species of Microtus in Jackson Hole, Wyoming. J. Mammal. 32:118-120.

Findley, J.S. 1951. A record of moose speed. J. Mammal. 32:116.

Findley, J.S. 1951. A tame red fox cub. J. Mammal. 32:117.

Findley, J.S. 1954. Reproduction in two species of Myotis in Jackson Hole, Wyoming. J. Mammal. 35:434.

Fischthal, J.H. 1953. Hypocaryopllaeus gilae (Caryophyllaeidae) from the Utah chub, Gila atraria, in Wyoming. Proc. Helm. Soc. Wash. 20:113-117. 
Fisher, R. F., M.J. Jenkins and W.F. Fisher. 1985. Fire and the vegetative mosaic at Devil's Tower National Monument. pp. 11-24. In: Fire Management. (J.N. Long, ed.) Intermountain Society of American Foresters. Utah State University. Logan, UT.

Fisher, R.F. 1987. Fire and the prairie-forest mosaic of Devil's Tower National Monument. Am. Midl. Nat. 117:250-257.

Flack, J.A.D. 1970. Bird populations of aspen forests in western North America. Ph.D. Thesis. Univ. Wisconsin, Madison.

Flack, J.A.D. 1976. Bird populations of aspen forests in Western North America. Am. Ornith. Union Mon. No. 19. 97 pp.

Forde, J.H. 1983. The effect of fire on bird and small mammal communities in the grasslands of Wind Cave National Park. M.S. Thesis. Michigan Tech. Univ., Houghton. 140 pp.

Forde, J.H. 1985. Grassland habitat management using prescribed burning in Wind Cave National Park, SD. Prairie Nat. 16:97-110.

Forde, J.H. and N.F. Sloan. 1984. Comparison of avian survival rates derived from three methods. N. Am. Bird Bander 9:57.

Frank, D.A. and S.J. McNaughton. 1989. Aboveground biomass estimation with the canopy intercept method: a plant growth form caveat. Oikos 57:57-60.

Frank, D.A. 1990. Interactive ecology of plants, large mammalian herbiores and drought in Yellowstone National Park. Ph.D Thesis. Syracuse Univ., Syracuse. 126 pp.

Frank, D. A. and S. J. McNaughton. 1991. Stability increases with diversity in plant communities: empirical evidence from the 1988 Yellowstone drought. Oikos 59:366-362.

Franklin, W.L. and A. abdu-Nabi El-Absy. 1985. Application of freeze-marking to wildlife in the field: Prairie dogs. Iowa State J. of Res. 60:71-75.

French, N.R. 1955. Foraging behavior and predation by Clark Nutcracker. Condor 57:61-62.

French, N.R. 1959. Life history of the Black Rosy Finch. Auk 76:159-180.

French, N.R. 1959. Distribution and migration of the Black Rosy Finch. Condor 61:18-29.

French, N.R. and J.B. French. 1965. Rosy Finches of the high Rockies. pp. 422-432. In: The Bird Watcher's America, (O.S. Pettingill, Jr., ed.). McGraw Hill Book Co., Inc., NY.

French, N.R. 1968. Leucosticte atrata Ridgeway, Black Rosy Finch. pp. 365-372. In: Life Histories of North American Cardinals, Grosbeaks, Buntings, Towhees, Finches, Sparrows, and Allies (O.L. Austin, Jr., ed.). Smithsonian Inst. Bull. No. 237.

Garrett, M.G., J.L. Hoogland and W.L. Franklin. 1982. Demographic differences between an old and a new colony of Black-tailed Prairie Dogs. Am. Midl. Nat. 108:51-59.
Garrett, M.G. and W.L. Franklin. 1983. Diethylstilbestrol as a temporary chemosterilant to control Black-tailed Prairie Dog populations. J. Range Manage. 36:753-756.

Gartner, R. 1982. Prescribed fire effects in a cool season plant community, Wind Cave National Park, South Dakota. Abstract of 35th Annual Meeting of Soc. Range Mange.

Gartner, R. and E.M. White. 1983. Historical role of fire in the northern Great Plains and its use in management. Abstract of Annual Meeting of Ecol. Soc. Am.

Gilligan, J.P. 1954. Wildlife values in western wilderness area management. J. Wildl. Manage. 18:425-432.

Gould, E., N.C. Negus and A. Norvick. 1964. Evidence for echolocation in shrews. J. Exp. Zool. 156:19-38.

Gourley, R.S. and F.J. Jannett. 1975. Pine and montane vole age estimates from eye lens weights. J. Wildl. Manage. 39:550556.

Griffiths, H.M., W.A. Sinclair, I.M. Lee, and R.E. Davis. 1991. DAPI fluorescence versus DNA probes for detecting mycoplasmalike organisms in woody plants and insects. (Abstract) Phytopathology 81:1210.

Gutierrez, R.J. 1989. Hermatozoa from the spotted owl. J. Wildl. Dis. 25:614-618.

Haines, J.H. and K.H. McKnight. 1977. Notes on two American Hyoloscyphaceae on Aspen. Mycotaxon 5:423-431.

Hansen, P.F., G.R. Hoffman and A.J. Bjugstad. 1984. The vegetation of Theodore Roosevelt National Park, North Dakota: A habitat type classification. USDA For. Serv. Gen. Tech. Report RM-113. 35 p.

Hasfurther, V.R. 1978. Operation and design of evapotranspiration waste disposal systems. Eisenhower Consortium Bull. No. 6, 21 pp. U.S. For. Ser. Rky. Mtn. For. and Range Exp. Sta., Fort Collins, CO.

Hoffman, G.R. and R.R. Alexander. 1987. Forest vegetation of the Black Hills National Forest of South Dakota and Wyoming: A habitat type classification. U.S. For. Ser. Rky. Mtn. For. and Range Exp. Sta., Fort Collins, CO.

Houston, D.B. 1968. The shiras moose in Jackson Hole, Wyoming. Grand Teton Nat. Hist. Assoc. Tech. Bull. \#1. $110 \mathrm{pp}$.

Houston, D.B. 1969. Immobilization of the shiras moose. J. Wildl. Manage. 33:534-537.

Huckabee, J.W. 1965. Waterfowl population study in Jackson Hole, Wyoming. M.S. Thesis. Univ. Wyo., Laramie.

Huckabee, J.W., F.O. Cartan and G.S. Kennington. 1972. Environmental influence on trace elements in hair of 15 species of mammals. Oak Ridge National Lab., ORNL-TM$3747.38 \mathrm{pp}$.

Jackson, S.M., R.B. Smith and T.L. Olsen. 1984. Recent uplift of the Yellowstone caldera from precision gravity measurements. Trans. Amer. Geophys. Union 65:1118. 
Jannett, F.J. 1975. The "hip glands" of Microtus pennsylvanicus and $\mathbf{M}$. longicaudus (Rodentia: Muridae), voles "without" hip glands. Syst. Zool. 24:171-175.

Jannett, F.J. 1978. The density-dependent formation of extended maternal families of the montane vole, Microtus montanus nanus. Behav. Ecol. and Sociobiol. 13:245-263.

Jannett, F.J. 1978. Dosage response of the vesicular, preputial, anal, and hip glands of the male vole, Microtus montanus (Rodentia: Muridae), to testosterone propionate. J. Mammal. 59:772-779.

Jannett, F.J. 1980. Social dynamics of the montane vole, Microtus montanus as a paradigm. Biol. 62:3-19.

Jannett, F.J. 1981. Convergent evolution in the behavior of a shrew and a rodent. J. Mammal. 45:473-481.

Jannett, F.J. 1981. Albinism and its inheritance in populations of the montane vole. J. Heredity 72:144-146.

Jannett, F.J. 1981. Scent mediation of intraspecific, interspecific, and intergeneric agonistic behavior among sympatric species of voles (Microtinae). Behav. Ecol. and Sociobiol. 8:293296.

Jannett, F.J. 1981. Sex ratios in high-density populations of the montane vole, Microtus montanus, and the behavior of territorial males. Behav. Ecol. and Sociobiol. 8:297-307.

Jannett, F.J. 1982. Nesting patterns of adult voles, Microtus montanus, in field populations. J. Mammal. 63:495-498.

Jannett, F.J. 1984. Reproduction of the montane vole, Microtus montanus, in subnivean populations. Special Publ. Carnegie Mus. Nat. Hist. 10:215-224.

Jannett, F.J. 1986. Morphometric patterns among microtine rodents. I. Relative scent gland development in representative voles (Microtus). In: Chemical Signals in Vertebrates, Vol. IV: Evol. and Comp. Biol. (D. Duvall, D. Muller-Schwarze and R. M. Silverstein, eds.). Plenum Press. New York.

Jannett, F.J. 1990. Posterolateral gland positions among microtine rodents. pp. 109-124. In: Chemical signals in vertebrates 5 . (D.W. McDonald, D. Muller-Schwarze, and S.E. Natynczuk, eds.), Oxford University Press.

Jannett, F.J. and J.Z. Jannett. 1974. Drum-marking by Arvicola richardsoni and its taxonomic significance. Am. Midl. Nat. 92:230-234.

Jannett, F.J., J.Z. Jannett and M.E. Richmond. 1979. Notes on reproduction in captive Arvicola richardsoni. J. Mammal. 60:837-838.

Jannett, F.J. and R.A. Stehn. 1981. Male-induced abortion in various microtine rodents. J. Mammal. 62:369-372.

Jenkins, M.J. and R.F. Fisher. 1985. Fire management at Devil Tower National Monument. pp. 225-30. In: Fire Management (J.N. Long, ed.). Intermountain Soc. Am. For. Utah State Univ., Logan.
John, K.R. 1957. Comparative rates of survival of normal and deformed chub, Gila atraria Girard, in Two Ocean Lake, Teton County, Wyoming. Proc. Pennsylvania Aca. Sci. 31:77-82.

John, K.R. 1959. Ecology of the chub, Gila atraria with special emphasis on vertebral curvatures in Two Ocean Lake, Teton National Park, Wyoming. Ecology 40:564-571.

Jones, W.B. 1965. Response of major plant species to elk and cattle grazing in Northwestern Wyoming. J. Range Manage. $18: 218-220$

Keiter, R.B. 1985. On protecting the National Parks from the External Threats Dilemma. Land and Water Law Rev. 1985:355.

Keiter, R.B. and W. Hubert. 1986. Legal considerations in challenging external threats to Glacier National Park. Envir. Manage. 11:121-126.

Kennington, G.S. 1957. Influence of altitude and temperature upon rate of oxygen consumption of Tribolium confusum Duval and Camponotus pennsylvanicus moduc Wheeler. Physiol. Zool. 39:305-314.

Kennington, G.S. 1961. The influence of temperature and atmospheric pressure on the rate of oxygen uptake in Tribolium confusum. Ecology 42:212-215.

Kingston, N., K.L. Diem, and D. Mitchum. 1981. Diphyllobothrium cordecips: a tapeworm problem in Yellowstone lake fishes. Proc. 2nd Conf. Sci. Res. National Parks. 2:141-162.

Knapp, A.K. and W.K. Smith. 1981. Water relations and succession in subalpine conifers in southeastern Wyoming. Univ. of Chicago Bot. Gaz. 142:502-511.

Knight, D. H. 1987. Parasites, lightning, and the vegetation mosaic in wilderness landscapes. In: Disturbance and landscape heterogeneity (M. G. Turner, ed.). SpringerVerlag, NY.

Laycock, W.A. 1957. Seasonal periods of surface inactivity of the pocket gopher. J. Mammal. 38:132-133.

Laycock, W.A. 1958. The initial pattern of revegetation of pocket gopher mounds. Ecology 39:346-351.

Lehman, J.A. 1980. Upper-crustal structure beneath Yellowstone National Park from seismic refraction and gravity observation. M.S. Thesis. Univ. of Utah, Salt Lake City.

Lehman, J.A., R.B. Smith, M.M. Schilly and L.W. Braile. 1982. Crustal structure of the Yellowstone caldera from delay-time analyses and correlation with gravity data. J. Geophys. Res. 84:2713-2730.

Levi, H.W. and L.R. Levi. 1951. Report on a collection of spiders and harvestment from Wyoming and neighboring states. Zoologica 36:219-237.

Lichtwardt, R.W. 1967. Zygosphores and sport appendages of Harpella (Trichomycetes) from larvae of Simuliidae. Mycologia 59:482-491. 
Lichwardt, R.W. 1972. Undescribed genera and species of Harpellales (Trichomycetes) from the guts of aquatic insects. Mycologia 64:167-197.

Lichvar, R.W., E.I. Collins and D.H. Knight. 1985. Checklist of vascular plants for the Bighorn Canyon National Recreation Area, Wyoming and Montana. Great Basin Nat. 45:734746.

Loudenslager, E.J. and G.H. Thorgaard. 1979. Karyotypic and evolutionary relationships of the Yellowstone (Salmo clarki bouvieri) and the westslope (S. $\underline{c}$ lewisi) cutthroat trout. J. Fish. Res. Bd. Canada 36:360-365.

Loudenslager, E.J. and R.M. Kitchen. 1979. Genetic similarity between two forms of cutthroat trout, Salmo clarki, in Wyoming. Copeia 1979:673-678.

Loudenslager, E.J. and G.A.E. Gall. 1980. Geographic patterns of protein variation and subspeciation in cutthroat trout, Salmo clarki. Syst. Zool. 29:27-42.

Lowrie, D.C. and W.J. Gertsch. 1955. A list of the spiders of the Grand Teton Park area, with descriptions of some new North American spiders. Am. Mus. Novit. 1736:1-29.

Lowrie, D.C. 1967. Some life history data on several species of common spiders from the Jackson Hole area of Wyoming. Bull. So. California Acad. of Sci. 66:142-146.

Lowrie, D.C. 1968. The spiders of the herbaceous stratum of Jackson Hole region of Wyoming. Northwest Sci. 42:89100.

Lynch, J.C. and E.R. Vyse. 1979. Genetic variability and divergence in grayling, Thymallus arcticus. Genetics 92:263-278.

MacLeod, E.G. and J.K. Sheldon. 1971. Studies on the biology of the Chrysopidae. II. The feeding behavior of the adult of Chrysopa carnea (Neuroptera). Psyche 78:107-121.

Marston, R.A. and D.H. Haire. 1990. Runoff and soil loss following the 1988 Yellowstone fires. Great Plains-Rocky Mountain Geographical Journal 18:1-8.

McFeters, G. A., S.A. Stuart and S.B. Olson, 1978. Growth of heterotrophic bacteria and extracellular products in oligotrophic waters. Appl. Environ. Microbiol. 35:383-391.

McFeters, G.A. 1978. Interactions of algae and heterotrophic bacteria in an oligotrophic stream. pp. 57-61. In: Proc. Life Sci. Microbiol. Ecol. (M.W. Loutit \& J.A.R. Miles, eds.). Springer Verlag, NY.

McGee, J.M. 1982. Small mammal populations in an unburned and early fire successional sagebrush community. J. Range Manage. 35:177-180.

McHugh, T. 1958. Social behavior of the American buffalo Bison bison bison. Zoologica 43:1-40.

McKnight, K.H. 1969. A note on Discina. Mycologia 61:614-630.

McKnight, K.H. 1971. On two species of false morels (Gyromitra) in Utah. Great Basin Nat. 31:35-47.
McKnight, K.H. 1972. Two misunderstood species of Gyromitra (False Morel) in North America. Missouri Botanist 12:3547.

McKnight, K.H. 1976. On Lachnella populicola Seaver. Mycologia 68:1129-1132.

McKnight, K.H. and L.R. Batra. 1974. Scanning electron microscopy in taxonomy of Gryromitroid fungi. Missouri Botanist 13:51-64.

McKnight, K.H. 1975. A new species of Cortinarius (Telamonia) from the Rocky Mountains. pp. 177-182. In: Studies on Higher Fungi. A collection of papers dedicated to $\mathrm{Dr}$. Alexander $\mathbf{H}$. Smith on the occasion of his seventieth birthday (H.E. Bigelow and H.D. Thiers and J. Cramer, eds.). Royal Octaro, VI.

McKnight, K.H. and M.V. Dublin. 1979. A new Peziza from the snowbank flora of Western America. Beihefte Zur Sydowia, Annalec Mycologicio., Ser. II. 224-227.

McKnight, K.H. and V.B. McKnight. 1987. Field guide to the mushrooms of North America. Houghton Mifflin Co., Boston. 429 pp.

Merrifield, J. 1983. Using analog regions to assess the economic impact of federal land management policies. Prof. Geog. 35:299-302.

Merrill, E.H. and M.S. Boyce. 1991. Summer range and elk population dynamics in Yellowstone National Park. pp. 263273 In: Greater Yellowstone Ecosystem: Redefining America's wilderness (R. B. Keiter and M. S. Boyce, eds.) Yale Univ. Press.

Miller, D.D. 1955. A study of sex combs in Drosophila affinis and Drosophila athabasca. Trans. Amer. Microscop. Soc. 74:191-197.

Mills, J.D. and R.A. Marston. 1990. Spatial trends in channel morphology of the Snake river, Grand Teton National Park, Wyoming. Great Plains-Rocky Mountain Geographical Journal 18:108-117.

Millspaugh, S.H. 1991. A record of fire in the sediments of small lakes from Yellowstone National Park. M.S. thesis. Department of Geology and Planetary Sciences. University of Pittsburgh.

Millspaugh, S.H., and C.W. Barnosky. 1990. Calibrating modern charcoal records to reconstruct prehistoric fires in Yellowstone Park. Proceedings of Ecological Society of America Annual Meeting, Snowbird.

Minshall, G.W., and J.T. Brock. 1991. Observed and anticipated effect of forest fire on Yellowstone stream ecosystems. Chapter 10 In: The Greater Yellowstone Ecosystem: Redefining America's Wilderness Heritage (R.H. Keiter and M.S. Boyce, eds.). Yale University Press, New Haven.

Mizelle, J.D. and F.O Webb. 1953. Studies on monogenetic trematodes: Dactyloyridae from Alaska, Wisconsin and Wyoming. Am. Midl. Nat. 50:206-217. 
Morgan, P., D.D. Blackwell, R.E. Spafford and R.B. Smith. 1977. Heat flow measurements in Yellowstone Lake and the thermal structure of the Yellowstone caldera. J. Geophys. Res. 82:379-3732.

Morris, G.K. and D.T. Gwynn. 1978. Geographical distribution and biological observations of Cyphoderris (Orthoptera: Haglidae) with a description of a new species. Psyche. 85:147-167.

Morris, G.K., D.T. Gwynne, D.E. Klimas and S.K. Sakaluk. 1989. Virgin male mating advantage in a primitive acoustic insect (Orthoptera:Haglidae). J. Insect Behav. 2:173-185.

Nakamura, M. 1950. A survey of Pasteurella tularensis infection in the animals of the Jackson Hole area. Zoologica 35:129131.

Negus, N.C. 1950. Breeding of three-year-old females in the Jackson Hole Wildlife Park buffalo herd. J. Mammal. 31:463.

Negus, N.C. 1950. Fluctuation in the population of Neotoma cineria (woodrat) in Jackson Hole, Wyoming. J. Mammal. 31:196-197.

Negus, N.C. 1950. Habitat adaptability of Phenocomys in Wyoming. J. Mammal. 31:351.

Negus, N.C. and J.S. Findley. 1959. Mammals of Jackson Hole, Wyoming. J. Mammal. 40:371-381.

Negus, N.C. and P.J. Berger. 1971. Pineal weight response to a dietary variable. Experientia 27:215-216.

Negus, N.C. 1977. Reproductive strategy of Microtus montanus. J. Mammal. 58:347-353.

Negus, N.C., P.J. Berger and B.W. Brown. 1986. Microtine population dynamics in a predictable environment. Can. J. Zool. 64:785-792.

Negus, N.C. and P.J. Berger. 1987. Mammalian reproductive physiology: adaptive responses to changing environments. pp. 149-173. In: Current Mammalogy (H. Genoways, ed.). Plenum Press.

Negus, N.C. 1987. Cohort analysis: environmental cues and "diapause" in microtine rodents. In: Symposium on Population Biology and Life History Evolution (M. Boyce, ed.). Yale Univ. Press.

Noble, G.A. 1953. An intestinal amoeba from the prong-horned antelope. Trans. of the Amer. Microscop. Soc. 72:249-252.

Noble, G.A. 1958. Coprozoic protozoa from Wyoming mammals. J. Protozool. 5:69-74.

Noble, G.A. 1961. Stress and parasitism. I. A preliminary investigation of the effects of stress on ground squirrels and their parasites. Exper. Parasit. 11:63-67.

Noble, G.A. 1962. Stress and parasitism. II. Effect of crowding and fighting among ground squirrels on their coccidia and trichomonads. Exper. Parasit. 12:368-371.

Noble, G.A. 1966. Stress and parasitism. III. Reduced night temperature and the effect on pinworms of ground squirrels. Exper. Parasit. 18:61-62.
Noble, G.A. 1966. Stress and parasitism. IV. Cold stress and Entamoeba. Exper. Parasit. 19:264-268.

Norland, J.E., L.R. Irby and C.B. Marlow. 1985. Determination of optimum bison stocking rate in Theodore Roosevelt National Park, North Dakota. J. Environ. Manage. 21:225239.

Norse E.A., W.H. Romme, K.L. Rosenbaum, D.S.Wilcox, B.A. Wilcox, D.W. Johnston and M.L. Stout. 1986. Conserving biological diversity in our national forests. Wilderness Soc., Wash., D.C. $116 \mathrm{pp}$.

O'Neill, K.M. 1983. The significance of body size in territorial interactions of male beewolves (Hymenoptera:Sphecidae, Philanthus). Ani. Behavior 31:404-411.

Otis, R.M. 1975. Interpretation and digital processing of seismic reflection and refraction data from Yellowstone Lake, Wyoming. Ph.D. Thesis. Univ. of Utah, Salt Lake City.

Otis, R.M., R.B. Smith and M.A. Mayhew. 1977. Geophysical surveys of Yellowstone Lake, Wyoming. J. Geophys. Res. 82:3705-3718.

Patterson, R.L. 1952. Sage Grouse in Wyoming. Sage Books, Denver, $\mathbf{C O}$.

Pinter, A.J. 1965. Litter sizes of Microtus montanus in the laboratory. J. Mammal. 46:434-437.

Pinter, A.J. 1966. Responses of Microtus montanus to plants and plant extracts in the diet. J. Mammal. 46:596-601.

Pinter, A.J. 1968. Effects of diet and light on growth, maturation and adrenal size of Microtus montanus. Am. J. Physiol. 215:461-466.

Pinter, A.J. 1968. Hair growth responses to nutrition and photoperiod in the vole, Microtus montanus. Am. J. Physiol. 215:828-832.

Pinter, A.J. 1973. Pink-eyed dilution in a natural population of the Uinta ground squirrel. J. Heredity 64:106.

Pinter, A.J. 1978. Comparison of organ weights of wild and laboratory-reared Microtus montanus infected with Trypanosoma brucei gambiense. Am. Midl. Nat. 100:126134.

Pinter, A.J. 1979. Erroneous report of extreme dilution (c') in Microtus pennsylvanicus. J. Heredity 70:213-214.

Pinter, A.J. 1979. Dominant spotting from a natural population of the vole, Microtus montanus. J. Heredity 70:441-443.

Pinter, A.J. 1986. Population dynamics and litter size of the montane vole, Microtus montanus. Can. J. Zool. 64:14871490.

Pinter, A.J. 1988. Multiannual fluctuations in precipitation and population dynamics of the montane vole, Microtus montanus. Can. J. Zool. 66:2128-2132.

Pinter, A.J. and N.C. Negus. 1965. Effects of nutrition and photoperiod on reproductive physiology of Microtus montanus. Amer. J. Physiol. 280:633-638. 
Pinter, A.J. and A.K. McLean. 1970. Hereditary hairlessness in the montane vole, Microtus montanus. J. Heredity 61:112114.

Pinter, A.J. and N.C. Negus. 1971. Coat color mutations in two species of the vole, Microtus montanus and Microtus ochrogaster) in the laboratory. J. Mammal. 52:196-199.

Pinter, A.J., J.R. Seed, P.U. Ashman, S. Ackerman and L. King. 1975. The weight of the spleen adrenals and gonads during a chronic Trypanosoma brucei gambiense infection in laboratory-reared Microtus montanus. Am. Midl. Nat. 96:379-390.

Pinter, A.J., W.D. O'Dell and R.A. Watkins. 1988. Intestinal parasites of small mammals from Grand Teton National Park. J. Parasitology 74:187-188.

Pelton, J.R. 1978. The analysis of deformation-induced variations in orthometric height and gravity with application to recent crustal movements in Yellowstone National Park. Ph.D. Thesis. Univ. of Utah, Salt Lake City.

Pelton, J.R. and R.B. Smith. 1979. Recent crustal uplift in Yellowstone National Park. Science 206:1179-1182.

Pelton, J.R. 1982. Contemporary vertical surface displacements in Yellowstone National Park. J. Geophys. Res. 87:2745-2761.

Pletscher, D.H., R.R. Ream, R. Demarchi, W.G. Brewster, and E.E. Bangs. 1991. Managing wolf and ungulate populations in an internation ecosystem. Trans. North Am. Wildl. Nat. Resour. Conf. 56:539-549.

Pontius, R.W. 1973. Studies on the uptake of nitrate and ammonium by phytoplankton. M.S. Thesis, Univ. Wyo. 124 pp.

Pontius, R.W. and M. Parker. 1973. Food habits of the mountain whitefish, Prosopium williamsoni (Girard). Tran. Amer. Fish. Soc. 102:764-773.

Rausch, R. 1949. Paradilepsis simoni. A cestode parasitic on the osprey. Zoologica 34:1-3.

Rausch, R. and E. Schiller. 1949. A contribution to the study of North American cestodes of the genus Paruterina Fahrmann, 1906. Zoologica 34:5-8.

Reed, J.F. 1948. Botanical investigations in the Jackson Hole Wildlife Park. J. Colo.-Wyo. Acad. Sci. 3:40.

Reed, J.F. 1950. The meadows of the Jackson Hole Wildlife Park. J. Colo.-Wyo. Acad. Sci. 4:53.

Reed, J.F. 1952. The vegetation of the Jackson Hole Wildlife Park, Wyoming. Am. Midl. Nat. 48:700-729.

Romme, W.H. 1980. Fire history terminology: Report of the adhoc committee. pp. 135-37 In: Proceedings of the fire history workshop, 20-24 October, 1980, Tucson, Arizona (M.A. Stokes and J.H. Dieterich, eds.). USDA Forest Service General Technical Report RM-81.

Romme, W.H. and D.H. Knight. 1979. Fire and landscape diversity in Yellowstone National Park. Bull. Ecol. Soc. Am. 60:102 (Abstract).
Romme, W.H. and D.H. Knight. 1981. Fire frequency and subalpine forest succession along a topographic gradient in Wyoming. Ecology 62:319-326.

Romme, W.H. and D.H. Knight. 1982. Landscape diversity: the concept and applied to Yellowstone Park. BioScience 32:664-670.

Romme, W.H. and D.H. Knight. 1982. Fire and landscape diversity in subalpine forests of Yellowstone National Park. Ecol. Monogr. 52:199-221.

Romme, W.H., D.H. Knight, and J.B. Yavitt. 1982. Tree growth and basal area increment after mountain pine beetle outbreaks in lodgepole pine forest, Yellowstone National Park. Bull. Ecol. Soc. Am. 63:172 (abstract).

Romme, W.H. and D.H. Knight. 1983. Natural disturbance and landscape pattern in Yellowstone National Park. Bull. Ecol. Soc. Am. 64:85 (abstract).

Romme, W.H., D.H. Knight, and J.B. Yavitt. 1983. Mountain pine beetle outbreaks in the Rocky Mountains: regulators of primary productivity? J. Colo.-Wyo. Acad. Sci. 15:28 (abstract).

Romme, W.H., D.H. Knight, and J.B. Yavitt. 1986. Mountain pine beetle outbreaks in the Rocky Mountains: Regulators of primary productivity? Am. Nat. 127:484-494.

Romme, W.H. and D. G. Despain. 1989. Historical perspective on the Yellowstone fires of 1988. BioScience 39:695-699.

Romme, W.H. and M.G. Turner. 1991. Implications of global climate change for biogeographic patterns in the Greater Yellowstone Ecosystem. Cons. Biol. 5:373-386.

Roofe, P.G. 1960. The rate of flow of blood through capillaries in the olfactory lobe of the brain of Amblystoma tigrinum. Anat. Rec. 138:159-162.

Roofe, P.G. 1961. Blood constituents of Amblystoma tigrinum. Anat. Rec. 140:337-340.

Roofe, P.G., H.B. Latimer and L.S. Feng. 1961. Weights and linear measurements of the body and of some organs of the tiger salamander. Anat. Rec. 141:35-44.

Roofe, P.G. 1964. Weights and linear measurements of the body and organs of the tiger salamander, before and after metamorphosis, compared with the adult. Anat. Rec. 148:139-147.

Sabinske, D.W. and D.H. Knight. 1978. Variation within the sagebrush vegetation of Grand Teton National Park, Wyoming. Northwest Sci. 52:195-204.

Sakaluk, S.K., G.K. Morris and W.A. Snedden. 1987. Mating and its effect on acoustic signalling behaviour in a primitive orthopteran, Cyphoderris strepitans (Haglidae): the cost of feeding females. Behav. Ecol. and Soc. 21:172-178.

Sakaluk, S.K., A. Mason and M.C. Sakaluk. 1989. Northeasterly orientation and defense of nest entrances in the harvester and, Pogonomyrmex owyheei. J. Insect Behav. 2:261-266.

Sakaluk, S.K. and W.A. Snedden. 1990. Nightly calling durations of male sagebrush crickets, Cyphoderris strepitans: size, mating and seasonal effects. Oikos 57:153-160. 
Sakaluk, S.K. 1991. Sex for a song (dinner included). Natural History 9:66-73.

Salt, G.W. 1957. An analysis of avifaunas in the Teton Mountains and Jackson Hole, Wyoming. Condor 59:373-393.

Sauer, J.R. and M.S. Boyce. 1983. Density dependence and survival of elk in northwestern Wyoming. J. Wildl. Manage. 47:31-37.

Sax, J.L. and R.B. Keiter. 1987. Glacier National Park and its neighbors: A study of federal interagency relations. Ecol. Law Quarterly 14:207-263.

Schaller, G.B. 1964. Breeding behavior of the white pelican at Yellowstone Lake, Wyoming. Condor 66:3-23.

Scherba, G. 1961. Nest structure and reproduction in the moundbuilding ant Formica opaciventris Emery in Wyoming. J. New York Entomol. Soc. 69:71-87.

Scherba, G. 1963. Population characteristics among colonies of the ant Formica opaciventris (Hymenoptera:Formicedae). J. New York Entomol. Soc. 71:219-232.

Scherba, G. 1964. Analysis of inter-nest movement by workers of the ant Formica opaciventris (Hymenoptera:Formicedae). Ani. Behav. 12:508-512.

Scherba, G. 1964. Species replacement as a factor affecting distribution of Formica opaciventris Emery (Hymenoptera: Formicidae). J. New York Entomol. Soc. 72:231-237.

Scherba, G. 1964. An analysis of inter-nest movement by workers of the ant, Formica opaciventris. Am. Zool. 4:162.

Scherba, G. 1965. Observations on Microtus nesting in ant mounds. Psyche 72:127-132.

Schilly, M.M. 1979. Interpretation of crustal seismic refraction and reflection profiles from Yellowstone and the eastern Snake River Plain. M.S. Thesis. Univ. Utah, Salt Lake City.

Schilly, M.M., R.B. Smith, J. Ansorge, J.H. Lehman and L.W. Braile. 1982. The Yellowstone-eastern Snake River Plain seismic profiling experiment: Upper-crustal structure. J. Geophys. Res. 84:2692-2704.

Schripsema, J.R. 1977. Ecological changes on pine-grassland burned in spring, late spring and winter. M.S. Thesis. South Dakota State Univ., Brookings. 99 pp.

Scogin, R. and C.E. Freeman. 1987. Floral anthocyanins of the genus Penstemon: Correlations with taxonomy and pollinators. Biochem. Syst. and Ecol. 15:355-360.

Sherburne S.S. 1991. Subnivean access point use by marten in Yellowstone National Park. M.S. Thesis. Utah State Univ. 80 pp.

Sherrod, B.S. 1989. Paleolimnology of Alder Lake and its implications for Holocene tectonics in Yellowstone National Park. M.S. thesis. Department of Geology and Planetary Sciences. University of Pittsburgh.
Shown, D.A. 1982. The effects of prescribed burning on bird and small mammal communities in the grasslands of Wind Cave National Park. M.S. Thesis. Michigan Tech. Univ., Houghton. 94 pp.

Shuey, R.T., R.O. Ugland and C.R. Schmit. 1977. Magnetic properties and secular variation in cores from Yellowstone and Jackson Lakes, Wyoming. J. of Geophys. Res. 82:3739-3746.

Shuey, R.T., D.K. Schillinger, A.C. Tripp and L.B. Alley. 1977. Curie depth determination from aeromagnetic spectra. Geophys. J. Royal Astronomical Soc. 50:75-101.

Sinclair, W.a., H.M. Griffiths, M. Treshow, and R.E. Davis. 1991. Ash yellows endemic in Zion National Park, Utah. (Abstract) Phytopathology 81:1235.

Smith, D.R. 1959. Changes in interspecific associations as related to grazing pressures. J. Range Manage. 12:309-311.

Smith, D.R. 1960. Description and response to elk use of two mesic grassland and shrub communities in the Jackson Hole region of Wyoming. Northwest Sci. 34:25-36.

Smith, D.R. 1961. Competition between cattle and game on elk winter range. Bull. 377. Univ. Wyo. Agr. Exp. Sta., Laramie. 16 pp.

Smith, R.B. 1977. The Yellowstone Symposium. J. Geophys. Res. 82:3663.

Smith, R.B. 1982. Introduction to special symposium volume, Yellowstone-Snake River Plain. J. Geophys. Res. 84:2581.

Smith, R.B., R.T. Shuey, R. Freidline, R. Otis and L. Alley. 1974. Yellowstone Hot Spot: New magnetic and seismic evidence. Geol. 2:451-455.

Smith, R.B., R.T. Shuey, J.R. Pelton and J.P Bailey. 1977 Yellowstone hot spot: contemporary tectonics and crustal properties from earthquake and aeromagnetic data. J. Geophys. Res. 82:3665-3676.

Smith, R.B. and R.L. Christiansen. 1980. Yellowstone Park as a window on the Earth's interior. Sci. Am. 242:104-117.

Smith, R.B., L.W. Braile, M.M. Schilly, J. Ansorge, C. Prodehl, M. Baker, J.H. Healey, St. Mueller and R. Greenfelder. 1982. The Yellowstone-eastern Snake River Plain seismic profiling experiment: General crustal structure Yellowstone. J. Geophys. Res. 84:2583-2596.

Smith, R.B. and W.J. Arabasz. 1991. Seismicity of the intermountain seismic belt. In: Neotectonics of North America: (D.B. Slemmons, Engdahl, E.R., Zoback, M.D., Zoback, M.L., and Blackwell, eds.). Geol. Soc. of Am., Boulder, CO. SMV V-1.

Solheim, W.G. 1960. Mycoflora Saximontanensis Exsiccata. Centum XI and XII. Univ. Wyo. Publ. 24(3 \& 4):22-33; 34-55.

Solheim, W.G. 1970. Mycoflora Saximontanensis Exsiccata. Centum XIV. Univ. Wyo. Publ. 36:51-67. 
Solheim, W.G. 1970. Mycoflora Saximontanensis Exsiccata. Centum XV. Univ. Wyo. Publ. 36:69-80.

Solheim, W.G. and G.B. Cummins. 1970. Mycoflora Saximontanensis Exsiccata. Centum XIII. Univ. Wyo. Publ. $36: 37-50$.

Spencer, Warren P. 1950. The Drosophila of Jackson Hole, Wyoming-a taxonomic and ecological survey. Am. Midl. Nat. 43:79-87.

Spielman, A.P., J. Piesman, T.K. Ruebush II, D.D. Juranek, and M. S. Jacobs. 1981. Reservoir hosts of human babesiosis on Nantucket Island. Am. J. Trop. Med. Hyg. 30:560-56.

Stuart, S.A., G.A. McFeters, J.E. Schillinger and D.G. Stuart. 1976. Aquatic indicator bacteria in the high alpine zone. Appl. and Envir. Microbiol. 31:163-167.

Sullivan, M.B., L.R. Irby, and C.B. Marlow. 1989. Potential green ash browse in hardwood draws in Theodore Roosevelt National Park. Prairie Nat. 21:211-217.

Sutton, J.F. and C.C. Black. 1975. Paleontology of the earliest oligocene deposits in Jackson Hole, Wyoming. Part 1. Rodents exclusive of the Family Eomyidae. Annals of Carnegie Mus. 45:299-315.

Tepedino, V.J. and F.D. Parker. 1984. Nest selection, mortality and sex ratio in Hoplitis fugida (Cresson) (Hymenoptera: Megachilidae). J. of the Kansas Entomol. Soc. 57:181-189.

Tepedino, V.J. and M. Stackhouse. 1987. Bee visitors of sweetvetch, Hediparum boreale boreale (Leguminosae), and their pollen-collecting activities. Great Basin Nat. 47:314 318.

Thompson, R.S., P.J. Bartelein, C. Whitlock, S. Harrison, and W.G. Spaulding. 1991. Climatic changes in the western United States since 18,000 yr B.P. In: Global climates for 9000 and 6000 Years Ago in the Perspective of Glacial Climate Change (H.E. Wright, Jr., J.E. Kutzbach, W.G. Ruddiman, F.A. Street-Perrott, and T. Webb III, eds). University of Minnesota Press, Minneapolis.

Thornton, C.S. 1956. Epidermal modifications in regenerating and in non-regenerating limbs of anuran larvae. J. Exp. Zool. 131:373-394.

Thornton, C.S. 1956. The relation of epidermal innervation to the regeneration of limb deplants in Amblystoma larvae. J. Exp. Zool. 133:281-300.

Thornton, C.S. 1957. The effect of apical cap removal on limb regeneration in Amblystoma larvae. J. Exp. Zool. 134:357382.

Thornton, C.S. 1958. The inhibition of limb regeneration in urodele larvae by localized irradiation with ultraviolet light. J. Exp. Zool. 137:153-180.

Thornton, C.S. 1960. Influence of an eccentric epidermal cap on limb regeneration in Amblystoma larvae. Dev. Bio. 2:551569 :

Thornton, C.S. 1960. Regeneration of asensory limbs of Amblystoma larvae. Copeia 4:371-373.
Thurmond, W. 1967. Hypothalamic chromatophore-stimulating activity in the amphibians Hyla regilla and Ambystoma tigrinum. Gen. and Comp. Endo. 8:245-251.

Thurmond, W. 1967. Onset of chromatophore-stimulating activity by the hypothalamus and adenohypophysis in Hyla regilla and Ambystoma tigrinum. Gen. and Comp. Endo. 8:252257.

Thurmond, W. 1967. Intermedin-like activity by the pars distalis of the salamander Ambystoma tigrinum. Am. Zool. 7:7.

Thurmond, W. 1968. Onset of melanophore-stimulating activity of the pars distalis and pars intermedia of the tiger salamander Ambystoma tigrinum melanostictum. Am. Zool. 8:113.

Tiner, J.D. 1951. Observations on larval carnivore ascarids in rodents. J. Parasit. 37:21-22.

Tiner, J.D. 1952. Speciation in the genus Ascaris: Additional experimental and morphological criteria. J. Parasit. 38:57.

Tiner, J.D. 1953. The migration, distribution in the brain, and growth of ascarid larvae in rodents. J. Infect. Dis. 92:105113.

Tiner, J.D. 1953. Fatalities in rodents caused by larval Ascaris in the central nervous system. J. Mammal. 34:153-167.

Trimble, A.B. 1973. Seismicity and contemporary tectonics of the Yellowstone Park-Hegben lake region. M.S. Thesis. Univ. of Utah, Salt Lake City.

Trimble, A.B. and R.B. Smith. 1975. Seismicity and contemporary tectonics of the Hebgen Lake-Yellowstone Park region: J. Geophys. Res. 80:733-741.

Ugland, R.O. 1976. An investigation of paleomagnetic secular variation in the sediments of Yellowstone lake and Jackson Lake, Wyoming. M.S. Thesis. Univ. of Utah, Salt Lake City.

Watkins, R.A., W.D. O'Dell, and A.J. Pinter. 1989. Redescription of flagellar arrangement in the duck intestinal flagellate, Cochlosoma anatis, and description of a new species, Cochlosoma soricis from shrews. J. Protozool. $36: 555-559$.

Whisenant, S.G. 1985. Effects of fire and/or atrazine on Japanese brome and western wheatgrass. 1985 Proc. of Western Soc. of Weed Sci. 38:169-176.

Whisenant, S.G. and D.W. Uresk. 1989. Burning upland, mixed prairie in Badlands National Park. Prairie Nat. 21:221-227.

Whisenant, S.G. 1989. Modeling Japanese brome population dynamics. 1989 Proc. of Western Soc. of Weed Sci. 42:176-185.

Whisenant, S.G. and D.W. Uresk. 1990. Spring burning Japanese brome in a western wheatgrass community. J. Range Manage. 43:205-208.

Whisenant, S.G. 1990. Postfire population dynamics of Bromus japonicus. Am. Midl. Nat. 123:301-308.

Whitfield, M.B. 1983. Bighorn sheep history, distributions, and habitat relationships in the Teton Mountain range, Wyoming. M.S. Thesis. Idaho State Univ., Pocatello. 
Whitlock Barnosky, C. 1990. A review of the late-Pleistocene glacial climate of the northwestern U.S. inferred from paleovegetation data [abstract]. Proceedings of the Geological Society of America, Rocky Mountain Section, Jackson.

Whitlock Barnosky, C. 1990. Long-term vegetational changes at contrasting elevations in the northwestern U.S. [abstract]. Proceedings of Ecological Society of American Annual Meeting, snowbird.

Whitlock, C. and P.J. Bartlein. 1991. Analysis of the patterns of Holocene climatic change in the Northern Rocky Mountains (abstract). Proceedings of the Geological Society of America Annual Meeting, San Diego.

Whitlock, C., S.C. Fritz, and D.R. Engstrom. 1991. A prehistoric perspective on Yellowstone's Northern Range. pp. 289-305. In: The Greater Yellowstone Ecosystem: Redefining America's Wilderness Heritage (R.B. Keiter and M.S. Boyce, eds). Yale University Press.

Whitlock, C. and S.H. Millspaugh. 1991. Development of a Fire History in Yellowstone National Park. [abstract]. Proceedings of Annual Meeting of the Association of American Geographers, Miami.

Whitlock, C., S.H. Millspaugh, and W.H. Harbert. 1990. Calibrating fire records in Yellowstone Park [abstract]. Proceedings of third annual meeting of research and monitoring on Yellowstone's northern range.

Williams, O. 1959. Food habits of the deer mouse. J. of Mammal. 40:413-419.
Wold, R.J., R.B. Smith and M.A. Mayhew. 1977. Geophysical study of a hydrothermal explosion crater in Mary Bay, Yellowstone Lake, Wyoming. J. Geophys. Res. 82:37333738.

Worcester, L.L. 1970. Effects of prescribed burning at different fuel moisture levels on vegetation and soils of grasslands in Wind Cave National park. M.S. Thesis. South Dakota State Univ., Brookings. 101 pp.

Worley, D.E. 1975. Observations on epizootiology and distribution of Elaeophora schneideri in Montana ruminants. J. Wildl. Dis. 11:486-488.

Wright, G.A. 1976. The coming of the People. Naturalist 27:8-19.

Wright, G.A. 1976. Prehistoric hunting of New World Wild Sheep: Implications for the study of sheep domestication. pp. 293-318. In: Cultural Change and Continuity (C.E. Cleland, ed.). Academic Press. N.Y.

Yoshiko, A. 1988. Riparian vegetation dynamics along the Bighorn River, Wyoming. M.S. Thesis. Univ. Wyo., Laramie.

Youmans, C.C. 1979. Characteristics of pocket gopher populations in relation to selected environmental factors in Pelican Valley, Yellowstone National Park. M.S. Thesis. Montana State Univ., Bozeman. 70 pp.

Zeveloff, S.L. 1980. The population status of Canada geese in Jackson Hole. J. Colo.-Wyo. Acad. Sci. 12:40. 